УДК 330.101.8+811.111’42:33

\title{
СПЕЦИФИКА СОВРЕМЕННОГО ЭКОНОМИЧЕСКОГО ДИСКУРСА КАК КАТЕГОРИИ*
}

\section{Т.В. СОЛОДОВНИКОВА}

канд. филол. наук,

ведущий научный сотрудник факультета международных отношений Белорусского государственного университета, г. Минск

\section{Аннотация}

B статье изложены теоретические подходы $\kappa$ определению современного экономического дискурса. Впервые экономический дискурс определен как универсальная категория, установлены его основные характеристики: идеологическая направленность, открытость, нелинейность, неустойчивость.

Ключевые слова: экономический дискурс, экономическая теория, экономический рост, категория, идеологическая направленность, открытость, нелинейность, неустойчивость.

\section{Abstract}

The article describes theoretical approaches to definition of modern economic discourse. For the first time economic discourse defined as a universal category, established its main characteristics: ideological orientation, openness, nonlinearity, instability.

Key words: economic discourse, economic theory, economic growth, category, all-scientific character, ideological orientation, openness, nonlinearity, instability.

\section{ВВЕДЕНИЕ}

В современной лингвистике дискурс-анализ бурно развивается, причем это развитие происходит не только за счет все более детального и глубокого изучения его в рамках этой науки, а прежде всего в рамках междисциплинарных исследований.

Как справедливо отмечалось в 2009 г. редколлегией электронного журнала «Современный дискурс-анализ»: «...концептуальная категория дискурса представляет собой основу для создания эффективных моделей междисциплинарных исследований, актуальность которых

\footnotetext{
* Статья подготовлена при финансовой поддержке БРФФИ (№ Г16М-017 от 20.05.2016).
} 
экспоненциально возрастает с развитием кризисных внутренних процессов в современных гуманитарных науках» [1].

Белорусские авторы в последнее время много пишут о проблеме самоидентификации отечественной экономической науки. Так, например, С.Ю. Солодовников отмечает, что «сегодня как никогда актуальна проблема самоидентификации белорусской экономической науки, выработка ее идеологической базы. По моему глубокому убеждению, без однозначного ответа на вопрос о том, какая философия хозяйствования должна быть положена в основу тех или иных теоретических построений, во имя чего мы все работаем, нельзя теоретически обосновать белорусскую экономическую модель, превратив экономическую науку в серьезное подспорье в определении направлений, форм и инструментов модернизации народного хозяйства» [2, с.56].

Названный автор также категорически заявляет, что в современной экономической науке, наблюдается парадоксальная ситуация, «когда представители различных экономических специальностей и школ, на основании проводимого ими мониторинга национальных экономик зачастую получают прямо противоположные выводы» [3, с.14].

\section{РЕЗУЛЬТАТЫ И ИХ ОБСУЖДЕНИЕ}

Одним из первых, кто вывел дискурс на уровень общегуманитарного исследования, по праву считается М. Фуко. Обратившись к различным наукам (медицине, экономике, грамматике), М. Фуко удалось установить дискурсивную природу любого знания, благодаря чему дискурс приобрел идеологические смыслы. Подобно Ж. Бодрийяру, М. Фуко сделал практически поструктуралистское допущение об отсутствии объекта и присутствии некоего его заменителя, который имеет дискурсивную природу: «Дискурс - это тонкая контактирующая поверхность, сближающая язык и реальность, смешивающая лексику и опыт» [4, с. 49]. В результате человек имеет дело не столько с миром, а сколько с продуктом общественной мысли, с одной из интерпретаций, которая по воле случая на данный исторический момент оказалась доминирующей.

В свою очередь, другой исследователь, представитель все той же структурной семиотики Р. Барт, обращая внимание на так называемую агрессивность дискурса, выделил «типы дискурсивного оружия» [5, с. 538]. Эту категорию он определил через интертекст. Дискурс включает в себя интертексты, в которых присутствует какое-то одно, общее для всех, свойство или признак. По его мнению «все культурные коды, будучи составлены из множества цитаций, в совокупности образуют небольшой, дикованно скроенный свод знаний, некую нелепицу: эта нелепица как раз 
и образует расхожую “реальность”, к которой приспосабливается и в которой живет индивид» [6, с. 205]. Таким образом, в своих работах Р. Барт вскрыл манипулятивную природу дискурса, который вынужден прибегать к ухищрениям и уловкам, чтобы представить своим пользователям естественное, «истинное» восприятие мира.

Очевидно, что при всем существующем многообразии трактовок, в которых дискурс становится единицей измерения процессов, явлений и т.д. определение является проблемным полем, которое моделируется в зависимости от объекта и целей изучения.

На наш взгляд, максимально релевантными признаками дискурса обладает определение Е.С. Кубряковой: «Дискурс может быть определен как такая форма использования языка в реальном (текущем) времени (on-line), которая отражает определенный тип социальной активности человека, создается в целях конструирования особого мира (или его образа) с помощью его детального языкового описания и является в целом частью процесса коммуникации между людьми, характеризуемого, как и каждый акт коммуникации, участниками коммуникации, условиями ее осуществления и, конечно же, ее целями» [7, с. 525].

Сегодня в зарубежной и отечественной экономической науке считается, что в процессе постижения объективных законов хозяйственной жизнедеятельности коренным гносеологическим вопросом является выбор методологических основ исследования, зависящий из достигнутого уровня социально-экономического и технологического развития общества, а также социально-классовой принадлежности исследователя. Именно эта принадлежность и определяет систему взглядов ученого, его внутренние идеологические установки, представления об общественном прогрессе и благе, которые непосредственно влияют на предпосылки и результаты проводимых исследований. «Если исходить из критериев логичности и аргументированности участников дискуссии о коренных методологических пороках маржинализма, неоклассики и т.д., то доказательств этому более чем достаточно. Вместе с тем, неправомерно сводить все дискуссии о природе рыночных отношений лишь к поиску научной истины. Ученые экономисты тоже люди. Они родились и воспитывались в определенной социально-культурной среде, обладают мотивацией, различными потребностями и интересами, наконец, их исследования финансируются из различных источников (а у субъектов, которые их контролируют, есть вполне реальные экономические потребности и интересы) и т.д.» [8].

Личностные характеристики ученых-экономистов, обусловливают, таким образом, известную заданность инструментов и результатов проводимых ими исследований, которые выступают откликом на 
своеобразный социальный заказ, даже если последний никак институционально не оформлен. Этот тезис подтверждается справедливым утверждением вышеупомянутого ученого, что «научное сообщество фаталистически обречено не только на постоянный поиск объективных закономерностей развития общества и его экономической системы, но и на выделение «ложных» концепций и преднамеренных концептуальных упрощений, обслуживающих глобальные экономические интересы вполне конкретных государств, классов, социально-экономических групп и индивидов» [8].

Это объясняет то, что на основании одних и тех же эмпирических данных экономисты делали и продолжают делать различные, а иногда и диаметрально противоположные выводы (например, П. Струве и киевская школа маржиналистов; К. Маркс и К. Каутский).

Вместе с тем последние исследования зарубежных и отечественных ученых показывают, что в современном мире все большее распространение получают экономические исследования, которые заведомо ориентированы на создание интеллектуального продукта, направленного не на постижение экономических законов и закономерностей, а на искажение мироощущения больших масс людей, навязывание им ложных мотивов и целей («эпоха вселенского обмана» Ч. Кирвель, «трансэкономика» и «трансполитика» - Ж. Бодрийяр). Ж. Бодрийяр при этом отмечает, что в современном европейском обществе «любая коммуникация, по сути, есть лишь принудительный сценарий, непрерывная фикция, избавляющая нас от пустоты нашего умственного экрана, на котором мы с не меньшим вожделением ждем изображения» [9, с. 22]. Согласно Ж. Бодрийяру, в современном информационном обществе «избыток знаний безразлично рассеивается по поверхности во всех направлениях, при этом происходит лишь замена одного слова другим» [9, с. 21]. В результате чего «написано и распространено столько знаков и сообщений, что они никогда не будут прочитаны. К счастью для нас! Ибо даже с той малой частью, которую мы абсорбируем, с нами происходит нечто, подобное казни на электрическом стуле» [9, с.49].

Говоря о путях преодоления кризиса экономической мысли П.С. Лемещенко и И.А. Лаврухина ставят на первое место ее «парадигмальное обновление» [10, с.34], что невозможно без целостной системы понятий. А эта система не может быть сформулирована без экономического дискурса. Такой подход во много корелирует с известным высказыванием Н.Н. Моисеева: «Возможность создания единого языка, единой системы методов, единого инструментария, которые могли бы быть использованы в исследованиях явлений разной 
природы, основывается на признании единства материального мира и, следовательно, единства наших знаний, на принципе познаваемости процессов, протекающих в живой и неживой природе, a также человеческом обществе» $[11$, с.7]. По мнению данных ученых, несмотря на появившийся в последние годы определенный прогресс в развитии белорусской экономической мысли, «это не предотвратило снижения общетеоретического уровня национальной экономической науки. И проявилось в предметно-методологической неопределенности, нарушении алгоритма исследования, размытости выводов, а также в преобладающем использовании интуитивно-описательного метода» [10, с.35].

Таким образом, под экономическим дискурсом следует понимать логически выстроенную систему рассуждений и доводов, основанную на общенаучных, социально-философских, исторических и политологических парадигмальных установках (последние в своей системной совокупности выступают методологией для политической экономии и экономической теории), которые позволяют в процессе научного обсуждения отсекать псевдонаучные, внеисторические, догматические рассуждения и, оставаясь в предметном поле экономической науки, не допускать снижения общетеоретического уровня науки и повышать ее прагматическое и апологетическое значение. Правильно организованный экономический дискурс позволит снизить существующую сегодня в белорусской экономической науке предметно-методологическую неопределенность, избежать нарушений алгоритма исследования и размытости выводов, а также уйти от все более преобладающего в последнее время интуитивноописательного метода.

Экономический дискурс представляется открытой динамической системой поскольку, во-первых, в ней постоянно идет процесс обмена информацией между субъектами экономической деятельности; во-вторых, в современных условиях глобализации постоянно меняются сущность и содержание экономических понятий и отношений, что ведет к нелинейности как самого процесса, так и результата; в-третьих, постоянно увеличивающееся информационно-концептуальное пространство экономики выводит систему экономического дискурса из устойчивого равновесия [12].

\section{ВЫВОДЫ}

Изложенное выше позволяет утверждать, что впервые экономический дискурс определен как универсальная категория. Выявлены признаки, которые легли в основу выделения его как категории. На основании 
исследования методологического состояния экономической науки, опирающегося в основном на мнения самих ученых-экономистов, удалось не только установить феноменологическую природу экономического дискурса, но и раскрыть его основные характеристики, среди которых: общенаучность, идеологическая направленность, открытость, нелинейность, неустойчивость.

Экономический дискурс - это сложное коммуникативное явление, обусловленное прежде всего социально-культурным контекстом; это дискурс, имеющий свои собственные цели, которые определяются типом социальной активности индивида; он всегда адресатен, поскольку имеет свою цель воздействия, и, как следствие, находится в постоянной борьбе с другими институциональными дискурсами.

Установлено, что под экономическим дискурсом следует понимать логически выстроенную систему рассуждений и доводов, основанную на общенаучных, социально-философских, исторических и политологических парадигмальных установках, которые позволяют в процессе научного обсуждения отсекать псевдонаучные, внеисторические, догматические рассуждения и, оставаясь в предметном поле экономической науки, не допускать снижения общетеоретического уровня науки и повышать ее прагматическое и апологетическое значение.

\section{ЛИТЕРАТУРА}

1. Современный дискурс-анализ. 2009. Выпуск 1. Том 1. Электронный журнал / Режим доступа: www.discourseanalysis.org. - Дата доступа: 27.05.2016 г.

2. Солодовников, С.Ю. Культ Карго, Или новый объект экономической науки / С.Ю. Солодовников // Белорусская думка. - 2016. № 1. - С. 56-62.

3. Солодовников, С.Ю. Цивилизация, культура, экономическая система общества и институциональные матрицы: феноменологическая природа и взаимообусловленность / С.Ю. Солодовников // Веснік Гродзенскага дзяржаўнага ўниверсітета імя Янкі Купалы. Сер. 5: Эканоміка, сацыялогія, біялогія. - 2011. - № 2. - С. 10-25.

4. Фуко, М. Археология знания: Пер. с фр. / М. Фуко; общ. ред. Бр.Левченко. - К.: Ника-Центр, 1996. - 208 с.

5. Барт, Р. Избранные работы: Семиотика. Поэтика / Р. Барт. М.: Прогресс, 1994. - 616 с.

6. Барт, P.S/Z / Р. Барт. - М.: РИК «Культура»; Ad marginem, 1994. $-303 \mathrm{c}$. 
7. Кубрякова, Е.С. Язык и знание / Е.С. Кубрякова. - М.: Рос. академия наук. Ин-т языкознания. - М.: Языки славянской культуры, 2004. - 560 с.

8. Солодовников, С.Ю. Гносеологические трудности при изучении классов и классовой борьбы в постиндустриальном обществе / С.Ю. Солодовников // Социологический альманах. - 2012. - № 3. C.74-91.

9. Бодрийяр, Ж. Прозрачность зла / Ж.Бодрийяр. - 5-е изд. - М.: «Добросвет», «Издательство "КДУ"», 2014. - 260 с.

10. Лемещенко, П.С., Лаврухина, И.А. Экономическая наука Беларуси: путь к самоидентификации / П.С. Лемещенко, И.А. Лаврухина // Вестник Ивановского государственного университета. - Серия «Экономика», Вып. 1(19), 2013. - С. 32-41.

11. Моисеев, Н.Н. Человек, среда, общество: Проблемы формализованного описания / Н.Н. Моисеев. - М.: Издательство «Наука», 1982. - 320c.

12. Тарасова, Е.В. Современный экономический дискурс в понятиях и терминах синергетики / Режим доступа: http:/dspace. nua.kharkov.ua/jspui/bitstream/123456789/309/1/\%D0\%A2\%D0\%B0\%D1\%80 $\% \mathrm{D} 0 \% \mathrm{~B} 0 \% \mathrm{D} 1 \% 81 \% \mathrm{D} 0 \% \mathrm{BE} \% \mathrm{D} 0 \% \mathrm{~B} 2 \% \mathrm{D} 0 \% \mathrm{~B} 0$.pdf.

Статья поступила в редакцию 24 ноября 2016 года. 